\title{
Effect of Aerobic Exercise and Gym-ball Exercise on the Liver Function Test Index, Adipokines, and Cardiovascular Risk Factors in Obese Children with Nonalcoholic Fatty Liver Disease
}

\author{
Sung Soo Lee* \\ Department of Coaching Collage of Sports Sciences, Dong-A University, Busan 604714, Korea
}

Received August 16, 2012 /Revised September 25, 2012 /Accepted September 25, 2012

\begin{abstract}
The aim of the present study was to investigate effects of a 12-week aerobic exercise training program and a gym-ball exercise training program on body composition, aspartate aminotransferase (AST), alanine aminotransferase (ALT), adipokines, and cardiovascular risk factors in obese children with nonalcoholic fatty liver disease. The subjects were separated into two groups, an aerobic exercise group $(n=10)$, which practiced moderate aerobic exercise training for 12 weeks, and a gym-ball exercise group $(n=13)$, which practiced resistance exercise training for 12 weeks. The results of the analyses are as follows: Weight, body mass index, and body fat were significantly lower $(p<0.01$, respectively), whereas the $\mathrm{VO}_{2}$ max was higher in both groups $(p<0.01)$. Fasting glucose, insulin and HOMA-IR levels were significantly decreased in the gym-ball exercise group $(p<0.05)$, whereas adiponectin, AST, and ALT levels were significantly increased $(p<0.05, p<0.001, p<0.001$, respectively) in both groups after the 12-week exercise training program. In addition, our results showed that HOMA-IR, insulin, and concentrations of C-reactive protein (CRP) were significantly lower in both groups. They demonstrate that a 12-week program of regular aerobic exercise or gym-ball exercise yields beneficial effects such as an amelioration of cardiovascular risk factors, body indices, and liver function in obese children with nonalcoholic fatty liver disease.
\end{abstract}

Key words : Adiponectin, aspartate aminotransferase (AST), alanine aminotransferase (ALT), CReactive Protein (CRP), homeostasis model assessment of insulin resistance (HOMA-IR)

\section{서 론}

최근 경제성장과 더불어 생활습관이 서구화되면서 식생 활 습관의 변화와 운동부족으로 인해 소아 비만 환자가 증 가하고 있다. 소아 비만은 성인 비만으로 이어질 가능성이 높을 뿐만 아니라, 비만으로 인해 소아 연령에서 성인병으 로 간주되는 당뇨, 고혈압, 심혈관 질환, 지방간 등이 발생할 수 있으므로 비만 아동의 장기적 예후에 미치는 영향이 매 우 크다[11].

비만과 관련된 비알코올성 지방간질환(non-alcoholic fatty liver disease: NAFLD)은 현대사회에서 실존하는 중요한 질병 중 하나이며, 만성 간질환의 가장 많은 원인 중 하나이다[3]. 비만에서 주로 발병하는 비알코올성 지방간질환에는 비교 적 예후가 좋은 단순 지방간(Simple fatty liver)과 함께 간의 섬유화가 진행되다가 나중에 간경화로 발전할 가능성이 있는 비알코올성 지방간염(non-alcoholic steatohepatitis: NASH) 등이 해당되므로 그 심각성이 최근 부각되고 있다[26]. Ludwig 등(1980)이 비알코올성 지방간염이라는 병리학적 소 견에 대해 처음 언급을 한 이래로 여러 연구에서 일부 지방간

*Corresponding author

Tel : +82-51-200-1064, Fax : +82-51-200-7805

E-mail : sky9850@dau.ac.kr
질환이 간경변이나 간세포 암으로 진행할 수 있다는 보고를 하였다[10,19]. 소아 지방간질환의 경우 성인에서 볼 수 있는 비알코올성 지방간질환과 유사하지만 성장기에 간 대사 이상 으로 인하여 발생한다는 점에서 다르다.

소아 비만 환자들에서도 비알코올성 지방간질환은 비교 적 흔히 볼 수 있는 비만 합병증이지만 아직 소아에서 발병 하는 비알코올성 지방간의 발생기전에 대한 논문은 그리 많 지 않다.

소아의 지방간 질환에 대한 보고는 1980년 중반부터 간혹 보고가 있었으나 본격적인 연구는 비교적 최근에 있었다. Rashid와 Roberts는 4-16세의 과체중인 소아 36명을 대상으로 간조직 검사를 시행하여 이 중 $71 \%$ 에서 간 섬유화가 있음을 보고하였으며, 그 이후에 보다 큰 규모의 임상연구에서는 대 부분의 소아 환자에서 고인슐린혈증과 인슐린 저항성이 있음 을 보고하였다[15,18]. 비록 조직학적 소견과 연관성이 있는 임상적, 혈액학적 소견을 관찰할 수 없었지만 적어도 소아 지 방간 질환이 탄수화물 대사와 연관된 인슐린 대사이상에 문제 가 있음을 제기하였다.

한편, 지방 조직의 생리적 작용에 대한 관심이 대두되면서 지방 조직에서 생성, 분비되어 대사를 조절하는 여러 adipokine들의 작용에 대한 연구 결과들은 계속적으로 발표되고 있 다. 비만한 환자에서 나타나는 adiponectin, leptin, tumor ne- 
crosis factor (TNF-a)와 같은 adipokine들의 증가 또는 감소는 인슐린 저항성을 포함한 비만 합병증에 대한 위험성 증가와 관련이 있는 것으로 알려져 있다[24,25].

이에 따라 최근 비알코올성 지방간염의 발현에 있어서 adipokine들의 역할과 작용에 대한 연구가 이루어지고 있으나, 소아 비만의 합병증으로 발병하는 비알코올성 지방간염의 발 병기전에 있어서 이러한 adipokine들의 작용에 대한 연구가 거의 없는 상태이다.

비알코올성 지방간은 임상적으로 간기능 검사 상 이상을 일으키는 가장 흔한 원인이며 만성 간질환의 주요 원인으로 보고되고 있다[1,4]. 최근 Schindhelm 등(2007)은 간기능 검사 상 이상이 있는 경우, 특히 alanine aminotransferase (ALT)의 상승이 죽상경화증(Atherosclerosis)과 심혈관 질환 위험도와 관련이 있음을 보고하였다. 이를 통해 비알코올성 지방간과 심혈관 질환 사이의 관련성을 추정할 수 있다. 이와 같이 비알 코올성 지방간의 발생 기전은 아직 확실하게 밝혀지지 않았으 나 간에서의 지방 축적은 복부 비만, 고혈압, 제 2 형 당뇨병, 지질대사이상 등 심혈관 질환의 위험요인과의 관련성이 제시 되었다[22,23].

따라서 성장기 아동들에서 비만이 계속적으로 증가하는 원인은 학업 스트레스와 불규칙적이고 잘못된 식습관 및 운 동부족 등으로 성인병의 유병률이 증가함에 따라 지방간의 빈도 역시 계속적으로 증가하고 있으며[17], 국내에서도 비알 코올성 지방간의 발생이 증가하여 이에 대한 관심이 증가하 고 있다.

이에 본 연구는 비만 아동들이 흥미롭고 재미있게 할 수 있는 짐볼(Gym-ball) 운동과 유산소 운동 프로그램을 통하여 비만 아동에서 발생하는 비알코올성 지방간과 adipokine및 심 혈관 질환 위험인자들의 변화를 규명하여 성장기 아동 및 청 소년들의 비만으로 인한 합병증 예방과 심혈관 질환 위험요인 감소를 위한 운동효과를 검증하고, 더 효과적인 운동 프로그 램을 개발하는데 그 목적이 있다.

\section{재료 및 방법}

\section{연구대상}

본 연구는 부산시에 거주하는 $\mathrm{A}, \mathrm{B}$ 초등학교에 재학중인 11 13세의 초등학생 20명을 대상으로 실시하였다. 본 실험에 앞서 본 운동프로그램에 참가를 희망하는 학생과 학부모에게 실험에 관한 전반적인 내용을 설명한 후 동의서에 서명을 받 고 전문의에 의한 의학적 검진을 실시하였다. 비만의 판정기 준은1998년 대한소아과학회에서 측정한 한국 소아의 표준 발 육치를 참고로 하여 BMI 백분위수가 >95\% 또는 비만도(\%) $>120 \%$ 에 해당하고, 의학적 검사에서 비알코올성 지방간을 가 진 어린이를 대상자로 선정하였다. 비만도는 한국 소아의 신 장별 체중 백분위의 50 백분위수의 값을 표준체중으로 하여
[비만도 $(\%)=($ 실측체중-표준체중 $) \times 100 /$ 표준체중]으로 계산하 여 비만 학생을 선정하였다. 모든 연구 대상자들은 최근 6개월 이내 정기적인 운동을 하지 않은 피험자들로서 짐볼 운동군 10 명, 유산소 운동군 10 명으로 구성하여 본 연구에 참여 시켰 다. 대상자의 신체적 특성은 Table 1과 같다.

\section{측정도구 및 방법}

\section{체격 및 신체구성 측정}

본 연구의 신체구성 변인인 신장, 체중, 체지방률은 임피던 스의 원리를 이용한 체성분 분석기(Venus 5.5, Jawon medical, Korea)를 이용하여 측정하였다. 체질량지수는 신장과 체중을 이용하여 계산하였다. 허리둘레는 줄자를 이용하여 직립자세 에서 12 번 늑골과 장골능선 가운데를 측정하였다.

\section{혈압측정}

혈압 측정은 혈액채취 시와 동일한 시간대에 표준화된 수은 혈압계(HICO, Japan)를 이용하여 최소 10 분간의 안정을 취하 게 한 후 좌측 상완을 심장과 동일한 높이로 하여 최고혈압과 최저혈압을 2회 측정하여 평균값을 산출하였다.

\section{최대운동부하검사와 운동강도 설정}

운동프로그램 실시 전과 12 주 후의 최대운동부하 검사방법 은 전자동 대사분석기(Quark b $b^{2}$ Cosmed, Italy)를 이용하여 변형된 Balke 트레드밀 프로토콜로 수행하였다. 최대운동부하 판정기준은 운동의 강도가 증가하여도 심박수가 증가하지 않 고, 산소섭취량이 $150 \mathrm{ml} / \mathrm{min}$ 이상 증가하지 않을 경우, 자각 적 운동강도(RPE; ratings of perceived exertion)가 17 이상 그리고 호흡교환율(RER; respiratory exchange ratio)이 1.15 이상 일 때로 하고 이것들 중 2 개 이상을 만족할 때 최대운동 부하로 판정하였다(ACSM, 2005). 12주간 유산소 운동 프로그 램을 위한 운동강도는 ACSM (2005)의 기준을 근거로, 중강도 (fast walking or jogging $50 \% \mathrm{HRR}$ )로 설정하고, ACSM의 대 사방정식 $\left[\mathrm{VO}_{2}=3.5+0.2\right.$ (속도) +0.9 (속도) $\times$ 경사도 $]$ 을 이용하여 사전실험을 통해 얻은 최대산소섭취량을 기준으로 피험자들 의 속도(speed)와 경사도(\% grade)를 산출하였다.

Table 1. Characteristics of subjects

\begin{tabular}{lcc}
\hline Variable & Aerobic $(\mathrm{n}=10)$ & Gym-ball $(\mathrm{n}=10)$ \\
\hline Age $(\mathrm{yr})$ & $12.10 \pm 0.57$ & $12.60 \pm 0.52$ \\
Height $(\mathrm{cm})$ & $146.01 \pm 7.47$ & $147.24 \pm 6.97$ \\
Weight $(\mathrm{kg})$ & $53.89 \pm 7.68$ & $54.43 \pm 6.80$ \\
BMI $\left(\mathrm{kg} / \mathrm{m}^{2}\right)$ & $25.16 \pm 1.47$ & $25.03 \pm 1.54$ \\
Body fat $(\%)$ & $28.26 \pm 2.89$ & $27.91 \pm 1.91$ \\
WHR & $0.90 \pm 0.06$ & $0.87 \pm 0.08$
\end{tabular}

Values are mean \pm S.D., BMI: Body mass index, WHR: Waist hip ratio 


\section{혈액분석}

혈액검사는 12 시간 이상의 공복 상태를 확인한 후 오전 9 시 부터 상완정맥에서 혈액 $10 \mathrm{ml}$ 채취하여, 각각의 수집된 혈액 샘플은 10 분 동안 원심분리한 후 혈청을 $-70^{\circ} \mathrm{C}$ 에 냉동 보관하 였다. 혈액 분석은 $\mathrm{D}$ 대학병원 약리학실험실에서 직접 aspartate aminotransferase (AST), alanine aminotransferase (ALT), Adiponectin, Leptin, Insulin, TNF- $a, \mathrm{CRP}$ 를 분석하였 다. 채혈 시기는 운동 전과 12 주 운동 후 운동의 마지막 효과를 배제하기 위해 72시간 경과한 후 동일한 조건에서 실시하였 다. 혈중 포도당 농도는 hexokinase법으로 자동분석기(Hichi, Japan)를 이용하여 측정하였다.

Total cholesterol (TC), triglyceride (TG)와 free fatty acid (FFA)는 automatic analyzer (Hitachi 736-20, Japan)를 이용하 여 효소법으로 분석하였다. Low density lipoprotein cholesterol (LDL-C)과 high density lipoprotein cholesterol (HDL-C)은 automatic analyzer (Hitachi 736-20, Japan)를 이 용하여 침전법과 직접법으로 분석하였다. 인슐린은 INC (limmuno Nucleo Cooperative, Stillwarer, USA) kit를 이용하 여 방사면역측정법으로 측정하였다. 또한 Adiponectin, Leptin, IL-6는 ELISA 법(AdipoGen, Seoul, Korea)을 이용하여 측정하였다.

\section{인슐린저항성 검사}

인슐린저항성은 공복혈당과 인슐린 농도를 이용하여 Homeostasis model assessment of insulin resistance (HOMA-IR)법으로 다음의 공식을 이용하여 계산하였다[12]. HOMA-IR=[fasting insulin $(\mathrm{uU} / \mathrm{ml}) \times$ fasting glucose $(\mathrm{mg} / \mathrm{dl}) / 405$

\section{운동프로그램}

유산소 운동 프로그램은 12 주간 주 3 일 빈도로 개인별로 산출된 운동강도(속도, 경사도, $\% \mathrm{HRR}$ )에 따라 $300 \mathrm{kcal}$ 에 도 달할 때까지 트레드밀 운동을 실시하였으며, 이 강도의 유지 를 위하여 심박수 측정기(X-trainer, Polar, Finland)를 이용하 여 모니터링 하였다. 운동처치 6 주 후에 체력이 향상됨에 따라 중간실험(최대운동부하검사)을 통하여 새로운 운동강도를 설 정하였으며, 12 주까지 그 강도로 트레이닝을 실시하였다. 운 동강도에 따른 유산소성 트레이닝 시 생리적 반응에 미치는 영향을 고려하여 트레이닝 기간 중에 모든 피험자들의 식생활 과 일상생활이 규칙적이 되도록 독려하였으며, 12 주간의 트레 이닝 기간 동안 탈락자를 예방하기 위하여 개인면담을 실시하
고, 수시로 격려하였다. 구체적인 유산소 운동 프로그램은 Table 2에 나타난 바와 같다.

짐볼 운동 프로그램은 학생들에게 전혀 경험이 없었기 때문 에 기본적인 짐볼을 이용한 스트레칭과 자기체중을 이용한 부위별 운동방법을 숙지한 후 운동을 실시하였다. 운동은 주 3 회, 1 회 60 분씩 총 12 주로 실시하였다. 짐볼 운동에 사용된 볼의 규격은 직경 $45 \mathrm{~cm}$ 로 피험자의 신장을 고려하여 선택하 였다. 짐볼운동은 $300 \mathrm{kcal}$ 에 도달할 때까지 실시하였으며, 이 강도의 유지 및 칼로리 소비를 확인하기 위하여 신체활동시 소비 에너지를 측정하는 시스템인 Actical (Philips, United Kingdom)을 이용하여 모니터링 하였다. 짐볼 운동 프로그램 은 Table 3에 나타난 바와 같다. 두 운동군 모두 운동시 소모되 는 칼로리량은 동일하게 하여 실시하였다.

\section{자료처리}

본 연구의 자료처리는 SPSS 19.0 을 사용하여 모든 자료에 대한 평균(M)과 표준편차(SD)를 산출하였다. 운동 프로그램 의 실시 전과 12 주 후의 차이검증은 Independent Sample t-test를 적용하여 통계적 의의를 분석하였고, 집단 내에는 Paired t-test를 실시하였다. 유의수준(a)은 $p<0.05$ 로 설정하 였다.

\section{결 과}

\section{신체조성의 변화}

두 운동군의 운동 전과 12 주 후의 신체조성의 변화는 Table 4 에 제시한 바와 같다. 유산소 운동군 내에서는 체중, BMI, 체지방률, $\mathrm{WHR}$ 이 각각 유의하게 감소하였고( $p<0.01, p<0.01$, $p<0.01, p<0.05)$, 짐볼 운동군 내에서도 체중, $\mathrm{BMI}$, 체지방률에 서만 각각 유의하게 감소하였다 $(p<0.05, p<0.05, p<0.01)$. 그러 나 집단 간에 유의한 차이는 나타나지 않았다. 체중당 산소섭 취량에서는 두 운동군 모두 유의하게 증가하는 것으로 나타났 고( $p \times 0.01)$, 수축기 및 이완기 혈압은 두 운동군 모두 운동 후 에 감소하는 경향을 보였으나, 운동 전과 비교하여 운동 후에 유의한 차이는 없었다.

\section{혈중지질, 인슐린 및 간 기능 검사지표의 변화}

운동 전과 12 주 후의 혈중지질, 공복시 혈당, 인슐린, 인슐린 저항성 및 간 기능 검사지표의 변화는 Table 5에 제시한 바와 같다. 유산소 운동군 내에서는 운동 전보다 운동 후HDL-C, $\mathrm{AST}, \mathrm{ALT}$ 에서 통계적으로 유의한 차이가 있는 것으로 나타났

Table 2. Aerobic exercise program

\begin{tabular}{lcccc}
\hline Section & Time $(\mathrm{m})$ & Intensity & Period & Frequency \\
\hline Warm-up & $10 \sim 15$ & & \\
Treadmill & 300 kcal consumed time & $50 \%$ HRR & 12 weeks & 3/week \\
Cool-down & $10 \sim 15$ & & & \\
\hline
\end{tabular}


Table 3. Gym-ball exercise program

\begin{tabular}{|c|c|c|c|}
\hline Section & Time (m) & Exercise program & Methods \\
\hline Warm-up & $10 \sim 15$ & Walking, Gymnastic \& Stretching & \\
\hline $\begin{array}{l}\text { Gym-ball } \\
\text { exercise }\end{array}$ & $50 \sim 60$ & $\begin{array}{l}\text { Gym-Ball Bear walking } \\
\text { Gym-Ball Push up } \\
\text { Gym-Ball Dumbbell press } \\
\text { Gym-Ball Shoulder press } \\
\text { Gym-Ball Dumbbell biceps curl } \\
\text { Gym-Ball One hand triceps extension } \\
\text { Gym-Ball Back extension } \\
\text { Gym-Ball Hip bridge } \\
\text { Gym-Ball Squat } \\
\text { Gym-Ball Twist lunge } \\
\text { Gym-Ball Leg curl } \\
\text { Gym-Ball Crunch }\end{array}$ & $\begin{array}{c}\text { 3/week } \\
\text { 10rep/2 3 set } \\
\text { RPE 10 12 intensity }\end{array}$ \\
\hline Cool-down & $10 \sim 15$ & Walking, Gymnastic \& Stretching & \\
\hline
\end{tabular}

Table 4. Change of body composition

\begin{tabular}{|c|c|c|c|c|c|}
\hline Variable & Group & Baseline & 12weeks & $t$-value & $p$ value \\
\hline \multirow{2}{*}{ weight (kg) } & Aerobic & $53.89 \pm 7.68$ & $50.76 \pm 7.38$ & \multirow{2}{*}{-0.751} & \multirow{2}{*}{0.462} \\
\hline & Gym-ball & $54.43 \pm 6.80$ & $52.09 \pm 5.96$ & & \\
\hline \multirow{2}{*}{ BMI $\left(\mathrm{kg} / \mathrm{m}^{2}\right)$} & Aerobic & $25.16 \pm 1.47$ & $23.70 \pm 1.62$ & \multirow{2}{*}{-0.854} & \multirow{2}{*}{0.405} \\
\hline & Gym-ball & $25.03 \pm 1.54$ & $23.99 \pm 1.56$ & & \\
\hline \multirow{2}{*}{ Body fat $(\%)$} & Aerobic & $28.26 \pm 2.89$ & $25.77 \pm 3.12$ & \multirow{2}{*}{-0.949} & \multirow{2}{*}{0.355} \\
\hline & Gym-ball & $27.91 \pm 1.91$ & $25.79 \pm 1.63$ & & \\
\hline \multirow{2}{*}{ WHR } & Aerobic & $0.90 \pm 0.06$ & $0.87 \pm 0.07$ & \multirow{2}{*}{-0.332} & \multirow{2}{*}{0.743} \\
\hline & Gym-ball & $0.87 \pm 0.08$ & $0.85 \pm 0.07$ & & \\
\hline \multirow{2}{*}{$\operatorname{VO} 2 \max (\mathrm{ml} / \mathrm{Kg} / \mathrm{min})$} & Aerobic & $32.30 \pm 4.81$ & $37.20 \pm 7.16$ & \multirow{2}{*}{0.753} & \multirow{2}{*}{0.461} \\
\hline & Gym-ball & $34.63 \pm 5.02$ & $38.26 \pm 4.32$ & & \\
\hline \multirow{2}{*}{$\mathrm{SBP}(\mathrm{mmHg})$} & Aerobic & $113.90 \pm 9.29$ & $111.10 \pm 4.25$ & \multirow{2}{*}{-0.464} & \multirow{2}{*}{0.648} \\
\hline & Gym-ball & $111.70 \pm 7.10$ & $110.20 \pm 8.73$ & & \\
\hline \multirow{2}{*}{ DBP (mmHg) } & Aerobic & $72.20 \pm 8.93$ & $70.20 \pm 6.18$ & \multirow{2}{*}{-0.577} & \multirow{2}{*}{0.571} \\
\hline & Gym-ball & $71.90 \pm 6.89$ & $70.40 \pm 3.53$ & & \\
\hline
\end{tabular}

Values are mean \pm SD, SBP; systolic blood pressure, DBP: diastolic blood pressure paired t-test: ${ }^{\#} p<0.05,{ }^{\# \#} p<0.01,{ }^{\# \#} p<0.001$, independent t-test: ${ }^{*} p<0.05,{ }^{* *} p<0.01,{ }^{* * *} \quad p<0.001$

고 $(p<0.001, p<0.001, p<0.001)$, 짐볼 운동군에서는 운동 전보다 운동 후 $\mathrm{TC}, \mathrm{LDL}-\mathrm{C}, \mathrm{TG}$ 가 유의하게 감소하였고 $(p<0.05$, $p<0.05, p<0.05), \mathrm{HDL}-\mathrm{C}$ 는 유의하게 증가하는 것으로 나타났 다 $(p<0.05)$. 그러나 집단 간에는 유의한 차이가 나타나지 않았 다. 그리고 Glucose, Insulin, HOMA-IR, AST, ALT도 12주 후 짐볼 운동군에서 유의하게 감소하는 것으로 나타났으나 $(p<0.05, p<0.05 p<0.05, p<0.001, p<0.001)$, 집단 간에는 유의한 차이가 없는 것으로 나타났다.

\section{Adipokine 및 심혈관질환 위험인자의 변화}

운동 전과 12 주 후의 Adiponectin 과 혈관염증인자의 변화 는 Table 6에 제시한 바와 같다. Adipokine인 Adiponectin 은
유산소 운동군과 짐볼 운동군 모두 각각 유의하게 증가하였고 $(p<0.05, p<0.01)$, Leptin은 두 운동군에서 각각 유의하게 감소 하는 것으로 나타났다 $(p<0.01, p<0.01)$. 그러나 집단 간에는 통 계적으로 유의한 차이는 나타나지 않았다.

심혈관 질환 위험인자인 $\mathrm{CRP}$ 는 유산소 운동군과 짐볼 운동군에서 각각 유의하게 감소하는 것으로 나타났으나 $(p<0.05, p<0.05)$, 집단 간에는 유의한 차이가 없는 것으로 나타났다

\section{고 찰}

최근 비만아동 인구가 증가하는 가장 중요한 원인은 현대 
Table 5. Chang of serum lipid and Liver function test index

\begin{tabular}{|c|c|c|c|c|c|}
\hline Variable & Group & Baseline & 12weeks & $t$-value & $p$ value \\
\hline \multirow{2}{*}{ TC (mg/dl) } & Aerobic & $152.30 \pm 15.20$ & $143.30 \pm 17.59$ & \multirow{2}{*}{1.394} & \multirow{2}{*}{0.180} \\
\hline & Gym-ball & $161.50 \pm 22.60$ & $143.00 \pm 16.17^{\#}$ & & \\
\hline \multirow{2}{*}{ HDL-C (mg/dl) } & Aerobic & $45.05 \pm 7.00$ & $56.63 \pm 9.06$ & \multirow{2}{*}{0.782} & \multirow{2}{*}{0.444} \\
\hline & Gym-ball & $46.06 \pm 7.99$ & $55.35 \pm 7.29^{\#}$ & & \\
\hline \multirow{2}{*}{ LDL-C (mg/dl) } & Aerobic & $96.10 \pm 13.96$ & $91.10 \pm 17.60$ & \multirow{2}{*}{1.822} & \multirow{2}{*}{0.085} \\
\hline & Gym-ball & $99.10 \pm 19.05$ & $85.30 \pm 16.70^{\#}$ & & \\
\hline \multirow{2}{*}{ TG (mg/dl) } & Aerobic & $111.80 \pm 69.57$ & $95.30 \pm 31.03$ & \multirow{2}{*}{0.204} & \multirow{2}{*}{0.840} \\
\hline & Gym-ball & $106.10 \pm 36.28$ & $85.50 \pm 34.82^{\#}$ & & \\
\hline \multirow{2}{*}{ Glucose $(\mathrm{mg} / \mathrm{dl})$} & Aerobic & $80.10 \pm 8.95$ & $70.50 \pm 12.72$ & \multirow{2}{*}{0.938} & \multirow{2}{*}{0.361} \\
\hline & Gym-ball & $80.90 \pm 9.96$ & $65.20 \pm 15.47^{\#}$ & & \\
\hline \multirow{2}{*}{ Insulin $(\mu \mathrm{U} / \mathrm{ml})$} & Aerobic & $27.91 \pm 27.23$ & $24.17 \pm 26.18$ & \multirow{2}{*}{0.422} & \multirow{2}{*}{0.678} \\
\hline & Gym-ball & $30.25 \pm 21.25$ & $23.97 \pm 20.21^{\#}$ & & \\
\hline \multirow{2}{*}{ HOMA-IR } & Aerobic & $5.83 \pm 6.58$ & $3.88 \pm 3.89$ & \multirow{2}{*}{-0.178} & \multirow{2}{*}{0.861} \\
\hline & Gym-ball & $6.09 \pm 4.20$ & $4.38 \pm 4.74^{\#}$ & & \\
\hline \multirow{2}{*}{ AST (IU/l) } & Aerobic & $75.30 \pm 12.90$ & $68.40 \pm 11.76^{\# \# \#}$ & \multirow{2}{*}{0.063} & \multirow{2}{*}{0.951} \\
\hline & Gym-ball & $79.10 \pm 6.90$ & $72.10 \pm 5.80^{\# \# \#}$ & & \\
\hline \multirow{2}{*}{ ALT (IU/1) } & Aerobic & $98.30 \pm 9.19$ & $88.90 \pm 7.43^{\# \# \#}$ & \multirow{2}{*}{-0.310} & \multirow{2}{*}{0.760} \\
\hline & Gym-ball & $101.00 \pm 7.13$ & $92.20 \pm 4.26^{\# \# \#}$ & & \\
\hline
\end{tabular}

Values are mean \pm SD, TG: triglyceride, TC: total cholesterol, LDL-C: low density lipoprotein cholesterol, HDL-C: high density lipoprotein cholesterol, AST: aspartate aminotransferase, ALT: alanine aminotransferase, paired t-test: ${ }^{\#} p<0.05,{ }^{\# \#} p<0.01, \# \#$ $p<0.001$, independent t-test: ${ }^{*} p<0.05,{ }^{* *} p<0.01,{ }^{* * *} p<0.001$

Table 6. Change of adipokine and cardiovascular risk factors

\begin{tabular}{|c|c|c|c|c|c|}
\hline Variable & Group & Baseline & 12weeks & $\mathrm{p}$ & $\mathrm{T}$ \\
\hline \multirow{2}{*}{ Adiponectin (ug/ml) } & Aerobic & $13.48 \pm 5.69$ & $16.29 \pm 3.21^{\#}$ & \multirow{2}{*}{0.265} & \multirow{2}{*}{0.794} \\
\hline & Gym-ball & $12.01 \pm 0.78$ & $14.68 \pm 3.11^{\# \#}$ & & \\
\hline \multirow{2}{*}{ Leptin (ug/ml) } & Aerobic & $15.15 \pm 5.12$ & $11.57 \pm 4.88^{\# \#}$ & \multirow{2}{*}{-0.494} & \multirow{2}{*}{0.627} \\
\hline & Gym-ball & $16.21 \pm 5.57$ & $13.25 \pm 4.31^{\# \#}$ & & \\
\hline \multirow{2}{*}{ CRP (mg/dl) } & Aerobic & $0.17 \pm 0.16$ & $0.14 \pm 0.11^{\#}$ & \multirow{2}{*}{0.842} & \multirow{2}{*}{0.411} \\
\hline & Gym-ball & $0.19 \pm 0.21$ & $0.11 \pm 0.09^{\#}$ & & \\
\hline \multirow{2}{*}{ TNF- $\alpha$ (ng/ml) } & Aerobic & $5.25 \pm 2.38$ & $4.74 \pm 2.13$ & \multirow{2}{*}{-0.648} & \multirow{2}{*}{0.525} \\
\hline & Gym-ball & $4.96 \pm 2.04$ & $4.30 \pm 1.52$ & & \\
\hline
\end{tabular}

Values are mean $\pm \mathrm{SD}, \mathrm{CRP}$ : c-reactive protein, TNF- $\alpha$ : tumor necrosis factor- $\alpha$ paired t-test: ${ }^{\#} p<0.05,{ }^{\# \#} p<0.01,{ }^{\# \# \#} p<0.001$, independent t-test: ${ }^{*} p<0.05,{ }^{* *} p<0.01,{ }^{* * *} p<0.001$

생활양식의 변화와 좌식생활의 증가로 인한 에너지 소비량 감소 때문이다. 특히 신체활동이 감소하고, TV시청과 컴퓨터 게임 등의 좌식생활이 일상생활 행동유형에 대부분을 차지하 고 있기 때문에 아동과 청소년들의 과체중과 비만 발생 위험 이 증가하고 있다[5,9].

따라서 본 연구에서는 12 주간 짐볼 운동과 유산소 운동 두 집단으로 나누어 운동을 실시하여 비알코올성 지방간을 가 지고 있는 비만아동들에게 어떤 운동이 더 효과적인지 실험 하였다.

운동과 신체조성의 변화에 관한 연구는 현재까지 많은 운동 관련 연구들에서 보고되고 있다. 그 중 Savoye 등(2007)은 체 질량지수 백분위수 95이상의 8 16세 209명을 대상으로 $\mathrm{HRmax} 65 \sim 80 \%$ 의 운동을 실시한 결과 체중, $\mathrm{BMI}$, 체지방량
이 유의하게 개선되었다고 보고하였으며, Benson 등(2008)에 따르면 10 15세 비만 청소년을 대상으로 8주간 $1 \mathrm{RM} 80 \%$ 의 근저항 운동을 실시한 결과 허리둘레와 체지방률이 유의하게 감소하였다고 보고하였다. 또 다른 선행연구에서도 비만학생 일부를 선발하여 규칙적인 운동을 6주간 실시한 결과 체중, $\mathrm{BMI}$, 중성지방이 유의하게 감소되었다고 보고하였다. 본 연구 에서도 유산소 운동군과 짐볼 운동군 모두 신체조성의 긍정적 인 변화를 나타냈다. 따라서 비만 아동을 대상으로 실시한 짐 볼 운동도 유산소 운동과 같은 긍정적인 운동효과가 있는 것 으로 나타나 규칙적인 운동은 신체조성의 긍정적 변화와 함께 비만의 치료 및 예방에 도움이 될 수 있을 것으로 생각된다. 또한 규칙적인 신체활동은 나이에 관계없이 비만한 사람들에 게 있어서 지질, 지단백 및 아포단백을 개선시켜 심혈관 질환 
을 예방한다고 보고되고 있어 규칙적인 운동의 실시가 중요하 게 인식 되고 있다[13,20]. 비만 중년 남성을 대상으로 유산소 운동과 저항운동을 실시한 결과 TC와 LDL-C가 유의하게 감 소하였고, HDL-C에서는 통계적으로 유의하게 증가한 것으로 나타났다[16]. Obisesan 등(2008)은 20분은 $\mathrm{VO}_{2} \max 50 \%$ 로 실 시하고, 40 분부터는 $\mathrm{VO}_{2} \max 70 \%$ 로 트레드밀 달리기를 한 결 과 HDL-C 농도가 유의하게 증가하였다고 보고하였다. 본 연 구에서는 선행연구 결과와 같이 유산소 운동군과 짐볼 운동군 에서 혈중 지질 및 인슐린 저항성 등 통계적으로 유의하게 나타났다. 이처럼 규칙적인 운동은 LDL-C를 감소시키고, $\mathrm{HDL}-\mathrm{C}$ 를 증가시켜 심혈관 질환을 예방하고 고혈압 및 고지 혈증을 개선하는데 도움이 될 것으로 사료된다. 또한 인슐린 저항성을 낮춤으로서 혈당조절 능력을 향상시켜 비만으로 인 해 당뇨병으로 이어질 수 있는 요인들을 예방할 수 있을 것으 로 생각된다.

최근 비만 및 대사증후군의 증가와 함께 급격히 증가하는 간질환으로 비알코올성 지방간이 사회적 문제로 야기되고 있 다. 비알코올성 지방간 환자의 $60 \sim 95 \%$ 에서 비만이, $30 \sim 55 \%$ 에 서 제 2 형 당뇨병이 동반되는 등 비알코올성 지방간이 대사성 장애와 동반되는 경우가 많아 간 내 인슐린 저항성 증가가 비알코올성 지방간 발생에 중요한 기전으로 보고 되고 있다. 그러나 아직 비알코올성 지방간을 가진 환자와 운동간의 관계 를 밝힌 연구는 없는 실정이다. 따라서 본 연구에서는 비만아 동들에게 긍정적인 운동효과를 가지고 있는 유산소 운동과 흥미를 유발할 수 있는 짐볼 운동을 실시하여 긍정적인 결과 를 나타내었다. 운동 전에 비해 운동 후 두 운동군에서 비알코 올성 지방간의 위험인자인 adiponectin, insulin, HOMA-IR, AST, ALT 모두 유의한 차이를 나타내었다. 이러한 연구결과 는 adiponectin은 비만환자에서 혈중 농도가 감소하는 것으로 보고되고 있는데, 이러한 adiponectin의 결핍은 비만 환자에 서 나타나는 인슐린 저항성과 관련이 있으며, 인슐린 저항성 은 결과적으로 비만과 관련된 심혈관계 질환 발생을 포함한 여러 합병증들의 위험성을 높일 가능성이 제시된 바 있다[6].

Hui 등(2004)에 의하면 비알코올성 지방간염이 있는 환자 들은 단순 지방간에 비해 낮은 adiponectin 값과 높은 HOMA-IR을 보였으나, 혈중 adiponectin이 감소할수록 간 조 직에서는 염증정도가 심한 양상을 보였다고 보고함으로써 adiponectin의 감소와 인슐린 저항성이 비알코올성 지방간염 의 발현에 어느 정도 기여할 것으로 결론을 내렸다. 또한 본 연구에서는 비알코올성 지방간을 가진 비만 아동들에게 운동 을 실시함으로서 혈중 adiponectin의 상승과 leptin이 감소하 는 것으로 나타났으며, HOMA-IR 역시 감소하는 것으로 나타 났다. 이는 운동을 실시함으로서 체중과 체지방의 감소와 함 께 인슐린 저항성의 개선효과로 간 기능 지수에도 긍정적인 영향을 미침으로서 비알코올성 지방간의 발생을 억제하는 효 과가 있는 것으로 사료된다.
또한, TNF- $a$ 는 인슐린 감수성을 감소시키며 염증매개 효과 를 보이는 상반된 작용을 갖는 것으로 알려져 있는데[8], 비만 환자들의 지방 조직에서 과발현 되어 인슐린 수용체의 tyrosine kinase 활성도를 감소시킴으로써 insulin signaling을 방해하여 비만 환자에서 인슐린 저항성을 유발하고 결과적으 로 간 내 지방축적을 초래할 수 있으며[7], 이와 동시에 TNF-a 가 갖는 염증 유발작용은 단순 지방간에서 비알코올성 지방간 염으로 진행하는 기전에 중요한 작용을 할 것으로 기대 되었 으나, 아직까지 이에 대한 연구가 그리 많지 않은 상태였다. 본 연구에서는 adiponectin과 더불어 비만 아동들에서의 비알 코올성 지방간 질환 발병에 있어 leptin, TNF- $a$ 의 의의를 평가 하여 보았으나, 그 결과 TNF-a 농도는 관련성이 없는 것으로 나타났다[26].

결론적으로 규칙적인 운동은 adiponectin향상과 함께 HOMA-IR이 감소되어 짐으로 AST와 ALT가 떨어지는 것으 로 나타났다. 따라서 유산소 운동뿐만 아니라 짐볼 운동과 같 이 규칙적인 운동은 비알코올성 지방간을 가진 비만 아동의 혈중지질과 간 기능 지수의 개선 및 혈중 adiponectin의 발현 증가로 인해 인슐린 저항성 역시 개선되므로 규칙적인 운동이 무엇보다 중요하다고 할 수 있다. 그러므로 비만의 치료 및 예방뿐만 아니라 비알코올성 지방간을 가진 환자들의 치료에 도 규칙적인 운동은 큰 도움이 될 것으로 생각된다.

\section{References}

1. Angulo, P. 2002. Nonalcoholic fatty liver disease. N. Engl. J. Med 346, 1221-1231.

2. Benson, A. C., Torode, M. E. and Fiatarone Singh, M. A. 2008. The effect of high-intensity progressive resistance training on adiposity in children: a randomized controlled trial. Int. J. Obes.(Lond). 32, 1016-1027.

3. Clark, J. M., Brancati, F. L. and Diehl, A. M. 2003. The prevalence and etiology of elevated aminotransferase levels in the United States. Am J. Gastroenterol. 98, 960-967.

4. Clark, J. M., Brancati, F. L. and Diehl, A. M. 2002. Nonalcoholic fatty liver disease. Gastroenterology 122, 1649-1657.

5. Eisenmann, J. C., Baetee, R. T., Smith, D. T., Welk, G. J. and $\mathrm{Fu}, \mathrm{Q}$. 2008. Combined influence of physical activity and television viewing on the risk of overweight in US youth. Int. J. Obes. 32, 613-618.

6. Fantuzzi, G. 2005. Adipose tissue, adipokines, and inflammation. J. Allergy Clin. Immunol. 115, 911-919.

7. Hotamisligil, G. S., Arner, P., Caro, J. F., Atkinson, R. L. and Spiegelman, B. M. 1995. Increased adipose tissue expression of tumor necrosis factor-alpha in human obesity and insulin resistance. J. Clin. Invest. 95, 2409-2415.

8. Hui, J. M., Hodg, A., Farrell, G. C., Kench, J. G., Kriketos, A. and Geroge, J. 2004. Beyond insulin resistance in NASH: TNF-alpha or adiponectin? Hepatology 40, 46-54.

9. Laurson, K., Eisenmann, J. C. and Moore, S. 2008. Lack of 
association between television viewing, soft drink, physical activity and body mass index in children. Acta. Paediatr. 97, 795-800.

10. Ludwig, J., Viggiano, T. R., McGill, D. B. and Oh, B. J. 1980. Nonalcoholic steatohepatitis : Mayo Clinic experiences with a hitherto unnamed disease. Mayo. Clin. Proc. 55, 434-438.

11. Mathur, P., Das, M. K. and Arora, N. K. 2007. Non-alcoholic fatty liver disease and childhood obesity. Indian J. Pediatr. 74, 401-407.

12. Matthews, D. R., Hosker, J. P., Rudenski, A. S., Naylor, B. A., Treacher, D. F. and Turner, R. C. 1985. Homeostasis model assessment: insulin resistance and beta-cell function from fasting plasma glucose and insulin concentrations in man. Diabetology 28, 412-419.

13. Nam, S. N. and An, S. H. 2008. The effect of combination exercise on body composition blood cholesterol and cardiac risk factors in middle obesity man. Korean Society of Exer. Physiol. 17, 49-58.

14. Neuschwander-Tetri, B. A. and Caldwell, S. H. 2003. Nonalcoholic steatohepatitis : summary of an AASLD Single Topic Conference. Hepatology 37, 1202-1219.

15. Nobili, V., Marcellini, M., Devito, R., Ciampalini, P., Piemonte, F., Comparcola, D., Sartorelli, M. R. and Angulo, P. 2006. NAFLD in children: a prospective clinical-pathological study and effect of lifestyle advice. Hepatology 44, 458-465.

16. Obisesan, T. O., Ferrell, R. E., Goldberg, A. P., Phares, D. A., Ellis, T. J. and Hagberg, J. M. 2008. APOE genotype affects black-white responses of high-density lipoprotein cholesterol subspecies to Aerobic exercise training. Metabolism 57, 1669-1676

17. Parti, D., Tailoi, E. and Zanella, A. 2002. Updated definitions of healthy ranges for serum alanine aminotransferase levels.
Ann. Intern. Med 137, 1-10.

18. Rashid, M. and Roberts, E. A. 2000. Nonalcoholic steatohepatitis in children. J. Pediatr. Gastroenterol. Nutr. 30, 48-53.

19. Sanyal, A. J. 2002. American Gastroenterological Association. AGA technical review on nonalcoholic fatty liver disease. Gastroenterology 123, 1705-1725.

20. Savoye, M., Shaw, M., Dziura, J., Tamborlane, W. V., Rose, P., Guandalini, C., Goldberg-Gell, R., Burgert, T. S., Cali, A. M., Weiss, R. and Caprio, S. 2007. Effects of a weight management program on body Composition and metabolic parameters in overweight children : a randomized controlled trial. JAMA. 297, 697-704.

21. Schindhelm, R. K., Dekker, J. M. and Nijpels, G. 2007. Alanine aminotransferase predict coronary heart disease events: a 10-year follow-up of the Hoorn study. Atherosclerosis 191, 391-396.

22. Tragher, G. and Arcaro, G. 2007. Nonalcoholic fatty liver disease and increased risk of cardiovascular disease. Atherosclerosis 191, 235-240.

23. Tragher, G., Bertolini, L. and Poli, F. 2005. Nonalcoholic fatty liver disease and risk of future cardiovascular event among type 2 diabetic patients. Diabetes 54, 3541-3546.

24. Trayhurn, P. and Wood, I. S. 2004. Adipokines: inflammation and the pleiotropic role of white adipose tissue. Br. J. Nutr. 92, 347-355.

25. Vettor, R., Milan, G., Rossato, M. and Federspil, G. 2005. Review article: adipocytokines and insulin resistance. Aliment. Pharmacol. Ther. 22, 3-10.

26. Yang, H. R., Ko, J. S. and Seo, J. K. 2007. The Role of Adipokines in the Pathogenesis of Non-alcoholic Fatty Liver Disease in Obese Children: the Relationship between Body Fat Distribution and Insulin Resistance. Pediatric Gastroenterology, Hepatol. Nutr. 10, 185-192.

\section{초록 : 유산소 운동과 짐볼 운동이 비알코올성 지방간 비만아의 간 기능평가 지수와Adipokine 및 심혈 관 질환 위험인자에 미치는 영향 \\ 이성수* \\ (동아대학교 스포츠과학대학 스포츠지도학과)}

본 연구에서는 12 주간 비알코올성 지방간을 가진 비만아동을 대상으로 유산소 운동군과 짐볼 운동군으로 나누 어 운동을 실시한 결과 체중, BMI, 체지방율이 유의하게 감소하였다. 또한 Adiponectin의 증가와 Leptin의 감소 로 인해 인슐린저항성과 혈당, 인슐린 농도도 유의하게 감소하는 것으로 나타났다. 또한 이러한 Adipokine들의 긍정적인 기능들로 인하여 비알콜성 지방간을 평가하는 간 기능 평가지수인 AST와 ALT도 감소하는 것으로 나 타났다. 결론적으로 비알코올성 지방간을 가진 비만아동뿐만 아니라 비알코올성 지방간 환자에 있어 유산소운동 뿐만 아니라 짐볼 운동에서도 운동효과가 유사하게 나타났으므로 규칙적인 운동은 심폐체력 증진 및 혈중지질의 감소와 함께 혈중 Adiponectin 발현을 증가시킴으로서 인슐린저항성 개선을 통하여 비알코올성 지방간 기능 개 선 뿐만 아니라 비만으로 인한 당뇨병, 심혈관 질환 발병의 예방에도 도움이 될 수 있을 것으로 기대된다. 